\title{
VERDICT OFF (DEATH PENALTY) FOR THE DRUG OFFENDER CRIME IN PERSPECTIVE OF ISLAMIC EDUCATION
}

\author{
Muhamad Tisna Nugraha \\ State Islamic Institute of Pontianak, Indonesia \\ E-mail: tisnanugraha2014@yahoo.com
}

\begin{abstract}
This paper raises the issue of the death penalty for drug-crime actors in Islamic education perspective, especially when the President Joko Widodo refused to pardon the actors at the beginning of his reign. Although the execution was likely contrary to the wishes of human right instigators, but on the other hand, such punishment is one vehicle in providing education to the citizens as well as the efforts to actualize the law enforcement in Indonesia. The implementation of the death sentence does not touch directly the scope of formal education in Indonesia. However, this is where the emerging hope and the search for enlightenment of such punishment is seen from the eyes of Islamic education which has applied the concept of reward and punishment in its system. Thus, through this paper, it is expected that educators can assist in bridging the imposition of a death sentence as an attempt to form good citizens.
\end{abstract}

Keywords: Death Penalty, Drugs, Islamic Education

\section{A. Introduction}

Punishment or verdict off (death penalty) for the actor of drug abuse offender and dangerous drugs, furthermore it is named as drugs. Increasingly in Indonesia published in media after the seventh President of Indonesia Ir. H. Joko Widodo, at the beginning of his leadership, he rejects a pardon of the death penalty for drug abuse offender. Frans $\mathrm{H}$. 
Winarta (2009: 180) stated that the death penalty as in all parts of the world are still controversial and become a human rights issue that is endless debated. Which is the most important? The deterrent effect and legal certainty or human life concerning for the human right to life as an individual and justice. Human should not vanish or eliminate another people for any reason.

This case is more interesting, because at the same time the majority of Muslims in Indonesia, precisely equate drugs with wine (liquor). According to Hasbiyallah (2006: 94), nowadays many kinds of drugs are more dangerous than alcohol, that is narcotics. Thus, the law of narcotics is same as wine (liquor). So, the interesting question arises, whether the death penalty for the drug abuse offender (courier, croupier and user), would apply equally for the makers, distributors, and for the people who drink wine (liquor).

Nowadays, validation of the death penalty in Indonesia and other countries including the United States is still debate controversially as well as human rights, especially when it is compared to the Universal Declaration of Human Rights, in the third chapter stated that; "Everyone has the right to livelihood, independence and safety of someone" (Sumarsono, 2012: 35). In addition, referring to the opinion of Cesare Beccaria, one of the activist of abolition of the death penalty (abolitionism) in Pranoto Iskandar (2012: 576) stated that the first, Beccaria doubt deeply impression and ancient which generated by the death penalty. Second, stated that acountry does not have a right to revoke human lives. Third, apenalty does not fulfill the principle of proportionality because the value of someone's life is not same value as the others. Fourth, a belief in the sanctity of life, and empirically even the death penalty is not shown as a deterrent factor in the creation of various crimes.

On the other hand, validation of the death penalty is still considered necessary to be applied when the offender commit an extraordinary crime and feared will redo the same crime. Moreover, the death penalty is also an effective and efficient way in providing education for the citizens about the impact of an extraordinary crime, as 
well as shock therapy, especially for the actors who have not been arrested.

If the validation of the death penalty is abolished, actually this is not a wise action, because it can lead to the number of the perpetrators of crimes are increasing and are delighted with the existing laws legal. Where the perpetrators do not need to feel afraid and worried with a crime that will or they have done, because they are sure that the heavy of the penalty given to them, certainly it is not the death penalty.

The principle of effectiveness and efficiency of the death penalty will be obvious when compared to the same offender, but with an imprisonment. Costs that must be payed by the government for offenders who verdicted an imprisonment relatively is too large, for example, in addition for preparing meals and drink for the offenders to life imprisonment. The government must provide free cost for electricity, water, security, doctor or nurse. Sometimes the psychologist is also needed. It is not proportionally to the crime that have been committed by the perpetrators or current condition of Indonesian society as the most of whom have to work hardly to get decent living. But from the point of view of economic reasons it is just for comparison, which is precisely the comparison between the bad impact of imprisonment caused by the widespread the use of drugs that have been and will kill teenagers especially in breaking the generation of the teenagers.

\section{B. Paradigm of Islamic Law about the Death Penalty for the Drug Offender}

1. Drug and Liquor

Drugs is an abbreviation of narcotics and dangerous drugs. Other terms of the drug is NAPZA which is an acronym for narcotics, psychotropic and other addictive substances. These terms refer to a group of substances contained in drugs and generally the impact ofthe risk is addiction and even the death for the users.

Based on estimation of the World Agency of Drugs (United Nations Office on Drugs and Crime) at the World Drug Report 2006, prevalence of drug abuse in the world of 5 percent of the world's population

TA'DIB, 20 (2), 2015, 311-326 
(approximately 200 million) last year. While in Indonesia, according to a survey of the National Narcotics Agency (BNN) and Puslitkes (2004), it is known that the prevalence of drug abuse amounted to 1.5 percent of the total population of Indoneisa (3.2 million). From these amount, there are about 572,000 users were identified as IDU potentially infected HIV and trigger the rapid spread of AIDS (Lubis, 2009: 294).

In Indonesia, drugs are classified into four main groups, as set in Law No. 35 of 2009, stated that class I and II are categorized as narcotics, as well as class III and IV as psychotropic and other addictive substances as stipulated in Law Number 5 in the Year of 1997.

Classification of drugs as described above is actually not detailed mention of all types or brands of drugs that existed in and outside of the country, because every year will always discover a new type of drugs. However, when referring to the impact caused by drug, actually drug can be equated with liquor, although not all of the drugs is absolutely prohibited, such as in the interest of medical or psychological.

As mentioned above, liquor comes from the word الخمر(al-khamru) which means covering. It is called covering because of the nature of these compounds are able to cover reasonable and make the users tend to heinous acts. While scholarly provides definitions liquor as everything which is intoxicating, either use a little or a lot. It is based on the hadith of the Prophet Muhammad;

$$
\text { عن ابن عمر قال قال رسول الله كل مسكر خمر وكل مسكر حر ام }
$$

Meaning: "From Ibn Umar r.a. (narrated that) he said: Messenger of Allah said: Every intoxicating is khamr, and every intoxicating is forbidden." (HR. Muslim)

From the hadith, it can be broadly understood that beside liquor, there is another type of food or beverage which eaten or drunk in a certain amount can be intoxicating the users. In addition, differences in habits and person's ability also affected. Al Qur'an does not specifically mention certain foods or beverages belonging liquor. Allah SWT said:

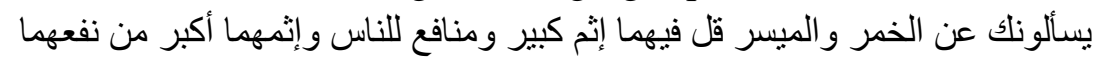


Meaning: "They ask you concerning to the liquor and gambling. Please say: "There is a great sin on both of them, and some benefits for humans, but the sin is greater than the benefits"... "(Qur'an, al-Baqarah, 2: 219).

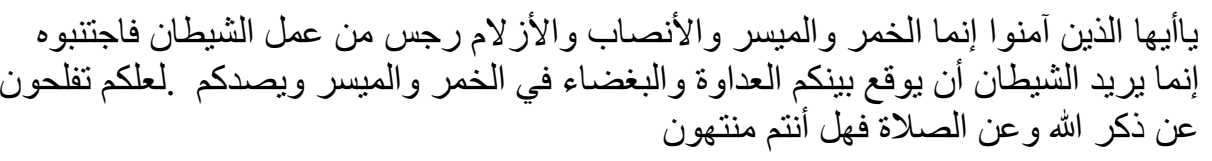

Meaning: "Oh you who believe, in fact (drinking) liquor, gambling, sacrifice for berhal, raffle fate with arrows are heinous acts. So stay away from those acts if you wan to get many prosper. Indeed Satan had meant to cause enmity and hatred among you because of drinking liquor and gambling, and hinder you from the remembrance of God and praying; then stop (doing those job). " (Qur'an, al-Maidah, 5: 90-91)

From the verse above, there is a word الخمر(liquor) with a sense of absolute, it's mean that there are no restrictions ban on drinking liquor. It means that liquor is forbidden to drink whether a little or a lot, whether through intoxicating or not. From the verse above, can be understood that the legal of drinking liquor is the same as the legal sacrifices to berhal (the statue), which is a kind of syirk where shirk include big sin.

\section{Death penalty and clemency in Islam}

Islam as a religion base on some forms of thinking and understanding the basic source of Islamic law, Al qur'an and Hadith. Through both of the legal basis is expected to be able to acquire a guidance for human physical and spiritual toward goodness in the world and hereafter. The existence of laws or rules in Islam is to realize these goals. In Islam, the law is seen as part of the rules of religion, and legal norms rooted in religion. Muslims believed that Islamic law based on the rules of God (Allah). Therefore, it is called as Shari'ah, which means the path leaded by God to man (Anwar, 2010: 3).

Once upon the time, the death penalty and clemency has been imposed Islam on the leadership of the Prophet Muhammad SAW,

TA'DIB, 20 (2), 2015, 311-326 
particularly when Fathu Makkah (the liberation of Makkah). During that time, there were about 17 people were given death penalty, but 11 of them were submitted for clemency and pardoned by the Prophet Muhammad SAW and 1 others managed to escape, on behalf of Hubairah bin Abi Wahab Makhzumi. The rest, or 5 people rejected the appeal for clemency and choose execute the death penalty, among them is Abdullah bin Khatal, Fartana, Huwairits bin Nafidz bin Wahab, Miqyas bin Subabh, and Harith bin Talatil.

The validation of death penalty is also valid at the time of the Prophet Muhammad SAW on the perpetrators of zinah fornication, jarimah hirabah, and murder. Nevertheless, in some cases, the penalty was not absolutely done by the Prophet Muhammad SAW, because the was no relief (rukhsoh ) in. For example, related to the unintentional murder (al-qatl al-khatha '), if the offender has pardoned the victim's family and are willing to pay diyat then Qisas against for the offender may be postponed.

Furthermore, validation of a death penalty is as part of the approach of Islamic law (see Salahuddin, 2012: 120) basically it has several objectives, including: maintaining religion (hifzh al-din), nourishes the soul (hifzh al-nafs), maintaining reasonable (hifzh al-'aql), maintaining descent (hifzh al-nasl), and maintaining the property (hifzh al mal). However, in the life history of the Prophet Muhammad SAW and the Khulafatur Rasyidin for the perpetrators who consume liquor will be given (whip) as much as 40 times, except for the leadership of Umar bin khatab, they are given as much as 80 times (ash-Syawi, 1997: 187). The explanation of the history above as explained below:

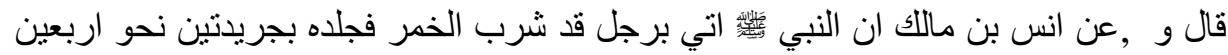
اخف الحدود ثمانين فامر به :فلما كان عمر استثار الناس فقال عبد الرحمن .فعله ابو بكر الثربن عمر.

Meaning: "From Anas RA, indeed the Prophet SAW never exposed to him, a man who had been drinking liquor. Then, he is hit by two palm branches (bat) as much as 40 times. Anas said, "The way was also done by Abu Bakr". But (at the time of 'Umar) after' Umar asked for the opinion of the Companions of the others, then the 'Abdur Rahman ibn' 
Auf said, "the lightest penalty is 80 times. Then 'Umar was told that whipped 80 times ". HR. Ahmad, Muslim, Abu Dawud and T (irmidzi. And Tirmidhi validated).

Validation of a death penalty for the perpetrators of liquor, once delivered by the Prophet Muhammad SAW in some histories, but does not apply absolutely, as follows:

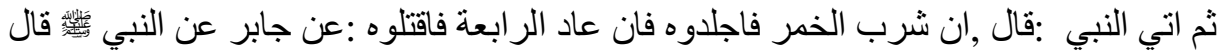
.

Meaning: "From Jabir, from the Prophet SAW, he said that," If (someone) drinks liquor, then whip him, then if he redo for the fourth times, then kill him ". Jabir said, "Then after that confronted a man who had been drinking liquor for the fourth times to the Prophet Muhammad SAW, but He just whipped and did not kill him". (HR, Muhammad ibn Ishaq in Nailul Authar 7, p 166)

Based on these history, the Prophet SAW did not like perpetrators who used liquor even threatened to impose severe legal form of a deathpenalty for the perpetrator. But in fact in that Hadith, he just does not impose the death penalty and the author did not obtain reference in execution at the time of the Prophet SAW related to the offenders of liquor. The death penalty may be considered as different situations and conditions among contemporary man such as Yusuf Al-Qaradawi (1995: 456), in which he stated that it is clear that marijuana, opium, heroin, morphine and the other including mukhaddirat (narcotics) especially types jeopardize that known as white poison-was forbiden and very forbiden by Muslims agreements, including the major sins that destroy, the user mandatory penalties, and distributors or traders must be given death penalty, because he traded the spirit of the people to enrich themselves.

Behind the controversy, as a form of obedience and compliance to the of state laws in the community and based on the deliberations of the Fatwa Commission Majelis Ulama Indonesia on October 20, 1975, October 30, 1975, 1 November 1975, 4 November 1975, January 26, 1976 and dated February 8, 1976 about "The Abuse of Narcotics" stated

TA'DIB, 20 (2), 2015, 311-326 
that, " in order to prevent drug abuse and the other which result in loss out of life and property are very disturbing mind, security and success of development, it need some efforts and actions such as heavy or hard penalty for the manufacturer, distributors, and narcotics smugglers materials to the death penalty. This is also supported by the Fatwa No. 10 / MUNAS VII / MUI / 14/2005 concerning on the permissibility of the death penalty in certain criminal acts, as well as Law No. 5 of 1997 about Psychotropic Article 59 that establishes the death penalty for the perpetrators.

\section{Relation Between Education and law}

Education is a conscious and deliberate effort in humanizing accordance to theeducation of Islam. Education is not only limited transfer of knowledge between teachers and learners, but also as a form of transformation of values and the formation of personality with all aspects in it, so that the success of an educational process is not be seen solely from the high and low values are obtained by the students in the class, but also the alteration in attitudes and behavior towards the better one after participating in the educational process.

Moreover, education is the process of internalization of culture into one's self and society, so it makes people and societies become more civilized. For this reason, the dimensions of education must include at least three of the most basic things as follow: (1) the affective which is reflected in the quality of faith and devotion, noble character, including noble character and superior personality and aesthetic competence; (2) cognitive reflected on the power of thought and intellectual capacity to explore, develop and master of science and technology; and (3) psychomotor reflected the ability to develop technical skills, practical skills and kinesthetic competence (Rustam, 2013: 112).

Based on the paradigm above, the objectives of Islamic education is a personal perfect believer achievement (perfect man), that is figure of believer qualified in religion, science and attitudes (see Education Law No. 20 of 2003) and at the effort in achieving the goal 
education as mentioned above, so there are several components that must be fill up, one of which is a component of instrumental input which includes the concept of awards (reward) and punishment.. It is as contained in the word of Allah QS. al-Zalzalah: 7-8:

Meaning: Whoever did good weighing as small as dzarrah, surely he would see the return, and whoever committed the crime as big as dzarrah, surely he would see the return.

From the above, it can be concluded that all forms of goodness will be rewarded, conversely, in doing crime. So that the concept and process of Islamic education, if learners do something good, then the return for a kindness is known as awards (reward) (see Silss, 1972: 320), while conversely, if students commit violations, then reply to the crime known as punishment.

The term of awards (reward) and punishment (punishment) are one of tools for many educational, basically they have the same function, which is equally directed learners in achieving educational goals. Word of punishment in the Qur'an, usually used lafadz 'iqab, adzab, or in the form of a statement. Elizabeth Ba Hurlock defines punishment, punishment means to impose a penalty on a person for a fault or offense or violation Retaliation ". Meaning: "The punishment is to impose a punishment of someone for an offense or mistake as a punishment or reward".

Based on various explanations above, penalties in Islamic education is an educative action (educating) as a warning and lesson for the violations that have been done. In addition, the penalty is shown to learners so that they become aware and avoid all kinds of abuses and errors of unwanted or at least they will be more careful in doing somethings.

Indeed, if you see the application of Islamic education in Indonesia at this time, it is certain none of the official agencies referred to the death penalty. Nevertheless, it does not mean in the process of education there is no punishment or sanctions against students who violate rules or regulations of that school, so this form of punishment 
can be replaced with a kind of another punishment and expected to create a deterrent effect for the perpetrators, such as the sanction suspension, no grade, or the issuing of learners from school if possible, which in this case is tantamount in turning off its ability to obtain education.

Basically, the punishment is a form of guidance and direction as well as efforts to control behavior with affection. Punishment should be given for the foundation of a good education and sincerity in sharing knowledge and not based on hatred, revenge and coercion. From this explanation, there is a paradigm shift from the concept of punishment as a form of retaliation, be a punishment as a vehicle of education and socialization. This is reflected from the word of prisons in Indonesia are not referred to by the House of Detention, but became a correctional institution (see Law No. 12 of 1995 concerning Corrections) assuming the perpetrators (of prisoners) will be taught at the institution in such a way as to be back to the public.

In the specific cases, the perpetrators are extraordinary crime, for example in this case is drug abuse. It can not be denied, the case is not just an ordinary criminal act that causes harm and death for person, but also can have a negative impact on a regency, provincial or damage to a country. Muhammad Asrun stated that, validation of the death penalty related to exceptional crimes such as narcotics must be seen as a safeguard against human rights life (the right to life) of many people. Although on the other hand, the application of these penalties which are qiyas as liquor in Islam and it has different implications in form of punishment.

Indeed, if you see the clasification of drug crimes as a crimes that must be given shock therapy for perpetrators and their derivatives, but on the other hand if it refers to the concept of Islamic education, it needs to be reviewed comprehensively. It is necessary an extraordinary action more sophisticated and innovative, so that justifications can be generated. 


\section{Stren Penalty for the Learners}

Several studies and previous research showed that to improve the motivation and efforts in achieving the goal, the prize of giving is seen as more effective than the sanction in the form of penalties such as: scolding, shaming public, hit and so forth. Although on the other hand, excessive gift-giving also feared could make learners just want to do something on the basis of the prize. Therefore Charles Schaefer (1989), stated that the educators efforted on how to eliminate the gift is not as often as possible, especially in the form of material, give the gift appropriately and not too excessive.

Related to problems of punishment in Islamic education, Ibn Jama'ah viewed that the judgment in the education can be classified by four forms. If the learners do the behavior unacceptable, educators can follow the following stages: First, prohibit the action was in front of students who make mistakes without using sarcasm or insult without naming the culprit or explain the traits that lead to a specific individual. Second, if learners do not stop it, educators can forbid it in secret, for example, by simply hand gestures. This is done to learners who understand cues. Third, if learners do not stop it, educators can forbid firmly and loudly, if circumstances demand it. It must be done so that learners and their friends abstain from doing and everyone who heard obtain lessons, learning by experiencing, that is learning from experience, in this case the experience that learners experinece or their friends who have viewed the experience. Fourth, if the learning never stop it, educators might throw them out and may ignore them until they returned from their wrong behavior, especially if the educators concerned about the actions that will be imitated by their friends, because learning by imitating or learning from imitating and in this case is imitating something which is wrong, there is something which is dangerous, especially at the ages of specific education such as basic education up to the age of pre-mature, easy to imitate is one of the characteristics of learners.

When educators want to apply the punishment of learners it should be done gradually and after giving stern warnings to such 
learners. In addition, the penalty must be in accordance with the mistakes that have been made by the learners, and based on social background, individual, gender and abilities of each individual. This is as stated in a hadith:

Meaning: "Command your children to pray at the age of seven years old and beat her/him for leaving him at the age of 10 years old and separate their beds". (Abu Daud No. 495 with Sanad Hasan).

Educating learners or students by punishment, either in the form of violence or coercion, actually just make them perform an action on the basis of fear and forced. This has an impact on all activities undertaken learners in the learning activities and will only be what it is, meaningless and informality (Budaiwi, 2002: 28). Preventive ways and detectives will not give the expected results, if it is not supported by the repressive actions. In fact, the main purpose of the enforcement of a penalty is not merely hurt the culprit, but the important thing is to make the culprit change or abandon such actions (deterrent).

\section{E. Principle in Giving Punishment for the Learners in Perspective of Islam}

From the knowledge that we get from the sources of Islamic teachings, basically education is done in a gentle way. However, when certain conditions that need to be done in a way that is firm, so the principle is not hurt, both physically and psychologically, as we have heard from a hadith that said when we hit someone intends to educate is in the part of body that is not expected feeling pain.

But unfortunately educating that does not hurt apparently is still not understood by some educators in Indonesia as we know several times from the mass media. For example, recently in February 2015, a learner in Majalengka suspected to have died of exhaustion while serving punishment time in the form of running for ten times around a basketball court of the school by educators because does not do the homework. 
One thing that is ironic, because the learners should be able to return to the bench of the class participating in learning activities at once determined to make amends with the task will be more activ in the class, but experienced an unexpected by many pars. Another example in educating, especially for the learners who are still young, must be done gently such when the Prophet Muhammad SAW was praying and his grandson climb his backs up, then gently lowered him from the back.

From these explanations, the penalty is essentially a method for repairing a person to be heading towards a better (see al-Abrasyi, 1990: 158-159), so that the educative punishment is a punishment that can provide a sense of sorrow at learners as a result of negligence action or behavior that is incompatible with the values that apply in their environment. However, if the penalty is only making the actors are emerging, or make the perpetrator even proud of his guilt, the question is whether the severe punishment be regarded as an effective punishment?.

\section{F. Conclusion}

Penalty or a death penalty can only kill the culprit, but did not kill his actions. Like cutting the grass in the park using a machine, it does not mean can turn off the roots. Therefore, when referring to the educational goals of Islam as an attempt to create a human personality, morals and devoted to Allah SWT, then the death penalty is not the only option of legal action that can be applied to the entire criminal or criminals outstanding. Moreover, it relates to the life of someone who is already a decree of Allah SWT. (see Ali Imran: 145).

When the death penalty in terms of the implementation of Islamic education in Indonesia, the application of this punishment certainly does not apply establishments in no one formal Islamic education, if any form of punishment is only in the form of warning, suspension, no grade, or strict sanctions such as dismissal or expelled from school. However, when viewed in the broader scope of the application of the death penalty in essence is one vehicle that can be 
done by the government in providing education to citizens about the importance of awareness and law enforcement.

Moreover, in the perspective of Islamic education, punishment can not walk alone, without coupled with the award (reward) as a unified whole effort to achieve educational goals. Furthermore, in the implementation of Islamic education an educator can not impose penalties directly before passing the stage of socialization (learning contract), guardianship, evaluation, reached the stage of action. It is intended as a form of approach to the theory of "white paper" as well as the presumption of innocence that learners basically do not know anything. 


\section{References}

Al Abrasyi, M. Athiyah. (1990). Dasar-Dasar Pokok Pendidikan Islam. Jakarta: Bulan Bintang.

Asy-Syawi, Taufiq Muhammad. (1997). Syura Bukan Demokrasi. Jakarta: Gema Insani Press.

Anwar, Syamsul. (2010). Hukum Perjanjian Syari'ah Studi Tentang Akad dalam Fiqh Muamalat. Jakarta: Rajawali Press.

Al-Baqi, Muhammad Fuad Abdi. (1992). Al-Mu'jam al-Mufahras li alFadz al-Qur'an. Beirut: Daar al-Fikr.

Budaiwi, A. Ali. (2002). Imbalan dan Hukuman Pengaruhnya bagi Pendidikan Anak. Jakarta: Gema Insani.

Hasbiyallah. (2006). Fikih Untuk Kelas VIII MTs. Bandung: Grafindo Media Pratama.

Iskandar, Pranoto. (2012). Hukum HAM Internasional Sebuah Pengantar Kontekstual. Bandung : IMR Press.

Kadar, M. Yusuf. (2011). Tafsir Ayat Ahkam, Tafsir Tematik ayat-ayat Hukum. Jakarta: Amzah.

Lubis, Todung Mulya dan Alexander Lay. (2009). Kontroversi Hukuman Mati Perbedaan Pendapat Hakim Konstitusi. Jakarta: Kompas Media Nusantara.

Qardhawi, Yusuf. (1995). Fatwa-Fatwa Kontemporer 2. Jakarta: Gema Insani Press.

Rustam, dkk. (2013). Konteks Pemikiran dalam Peradaban. Pontianak: STAIN Press.

Salahuddin, Muhammad. Ulumuna, Jurnal Studi Keislaman, Volume 16 Nomor 1 (Juni) 2012. Institut Agama Islam Negeri Mataram.

Sills, David L. (1972). International Encyclopedia of The Social Sciences. London: Collier Macmillan.

Sumarsono, S. (2006). Pendidikan Kewarganegaraan. Jakarta: Gramedia Pustaka.

Winarta, Frans H. (2009). Suara Rakyat Hukum Tertinggi. Jakarta: Kompas Media Nusantara.

Undang-Undang Narkotika Nomor 22 Tahun 1997 
Undang-Undang No 5 Tahun 1997

Undang-Undang Psikotropika Nomor 5 Tahun 1997

Undang-Undang Tentang Pemasyarakatan Nomor 12 Tahun 1995

UU Sisdiknas Nomor: 20 Tahun 2003 